\title{
Closing time: Reputational constraints on capital account policy in emerging markets
}

\author{
Steven Liao ${ }^{1} \cdot$ Daniel McDowell ${ }^{2}$ (D)
}

Accepted: 18 May 2021 / Published online: 23 July 2021

(C) The Author(s), under exclusive licence to Springer Science+Business Media, LLC, part of Springer Nature 2021

\begin{abstract}
Do international reputational concerns constrain governments' economic policy choices? We assess this question by analyzing emerging market decisions to tighten restrictions on capital outflows. While policymakers should be more likely to tighten restrictions to protect their economies as capital flow volatility (CFV) increases, investors view outflow controls as heterodox policies that violate investment contracts. We argue that the effect of CFV on outflow controls depends on the use of controls in peer markets. When peers are open, governments anticipate that controls will come at a high cost to their market reputations as heterodox measures send a negative signal to investors among a crowd of liberal peers. Conversely, when peers are closed, using controls should do less damage to an economy's reputation. For 25 emerging markets from 1995-2015, we show that CFV is associated with outflow controls, but only when market peers are already closed, suggesting reputational concerns can limit policy autonomy.
\end{abstract}

Keywords Capital controls $\cdot$ Emerging markets $\cdot$ Capital flow volatility $\cdot$ Reputation

\begin{abstract}
Responsible editor: Axel Dreher
We thank Joshua Aizenman, Erin Baggott Carter, David Dollar, Barry Eichengreen, Rachel Epstein, Phillip Lipscy, David Steinberg for their excellent feedback on earlier versions of the manuscript. We also thank participants at the ISA Annual Convention 2018, University of Southern California Political Economy of Asia's Monetary and Financial Landscape Workshop, and Cornell PSAC workshop. We thank Michael McCall for research assistance. Replication data and code are available on the Harvard Dataverse, at: https://doi.org/10.7910/DVN/E2WXJJ. Author contributions to theory and conceptualization: S.L. (25\%), D.M. (75\%); research design and statistical analysis: S.L. (75\%), D.M. (25\%); writing: S.L. (50\%), D.M. (50\%). The order of authors is chosen alphabetically.
\end{abstract}

Daniel McDowell

dmcdowel@maxwell.syr.edu

Steven Liao

steven.liao@ucr.edu

1 Department of Political Science, University of California, Riverside, Riverside CA 92521, USA

2 Department of Political Science, Syracuse University, Syracuse, NY 13244, USA 


\section{Introduction}

In an October 2018 interview on the sidelines of the World Bank and IMF annual meetings, Malaysia's central bank governor, Nor Shamsiah Mohd Yunus, discussed the need among Asian countries for more policy options to prevent financial crises. Yunus quickly zeroed in on capital controls, arguing they were "a legitimate policy tool that can be deployed in a pre-emptive manner to deal with potential risk to financial market stability" but then added, "I think there is still a lot of stigma in the use of capital [controls]" (Palma, 2018). These sentiments were echoed in an open letter published in the Financial Times and signed by 170 economists amid the capital market fallout from the COVID-19 pandemic. The signatories called for the broad use of outflow controls by developing countries to limit economic damage. Yet the letter also asserted that such policies must be coordinated by the IMF so governments could "avoid stigma" attached to the policy (Financial Times, 2020). Scholarship on capital controls has also argued this point. For example, Erten et al. (2019) suggest that "reputation effects may create a bias among policymakers against the use of capital controls, even under conditions when their use might otherwise be appropriate." Similarly, Chwieroth (2013) notes that "by raising the actual or perceived costs of a particular policy, stigmas may...encourage governments to pursue alternative policy choices." As these examples illustrate, policymakers, experts, and scholars regularly assert that the tools governments' may use in response to financial stability risks are constrained by concerns of reputational costs that may accompany capital account restrictions. But, to what extent are these claims supported by empirical evidence? Do international reputational concerns actually limit governments' financial policy choices in critical times?

We assess this broad question by focusing on one specific policy choice: emerging market decisions to tighten restrictions on capital outflows. Many studies have linked volatile cross-border financial flows to macroeconomic instability (Reinhart \& Rogoff, 2013; Calvo \& Reinhart, 1999). Though evidence on the effectiveness of outflow controls as a policy tool is mixed (IMF, 2012b, 6-7), both anecdotal and empirical evidence suggest that as capital flow volatility (CFV) increases, governments are more likely to tighten restrictions on outflows (Aizenman \& Pasricha, 2013). ${ }^{1}$ Yet, outflow controls are viewed with derision in financial markets as they violate established norms of capital freedom and property rights protection (Abdelal 2007; Chwieroth 2010; Edwards1999,82). Thus, when faced with CFV, governments must decide if the potential short-term macroeconomic stabilizing benefits of capital controls are worth a tarnished market reputation, thereby diminishing the attractiveness of their economy as an investment destination. Moreover, because reputations are "sticky," the damage a bad reputation inflicts on the economy's investment appeal is likely to endure even after controls are lifted (Demirguc-Kunt \& Serven, 2009; Goh, 2005).

\footnotetext{
${ }^{1}$ We use the terms "restrictions on capital outflows" and "capital outflow controls" interchangeably to refer to any policy that restricts (1) residents' ability to purchase financial assets abroad and (2) non-residents' ability to sell local financial assets.
} 
We argue that reputational considerations can constrain capital account policy choices. Because investors lack perfect information about the strength of a government's true commitment to liberalism, they observe current policy decisions and make inferences about the direction of future policies (Bartolini \& Drazen, 1997). The use of outflow controls in the present period sends a signal to investors about a government's future commitment to liberal policies-what we refer to as a market reputation. As the Yunus quote above suggests, policymakers recognize that their policy choices can cause investors to update their beliefs about the government's true "type" (Ghosh et al., 2020; Tomz, 2007). A government that resists using outflow controls earns an orthodox market reputation as investors perceive that it has a steadfast commitment to the free movement of capital across borders. Conversely, one that employs capital controls develops a heterodox market reputation as investors perceive that it lacks a commitment to financial openness, reducing its economy's appeal as an onshore investment destination in current and future periods.

Yet, we further assert that the anticipated level of reputational damage associated with outflow controls is not constant across time and space. When a country's market peers have open capital accounts, policymakers should worry that the use of outflow controls will come at a high cost to their market reputation. In this context, the use of illiberal policy tools will contrast starkly against liberal market peers, sending a strong negative signal to investors that the government has heterodox preferences, lacking a commitment to openness. On the other hand, the strength of the negative signal sent by outflow controls should attenuate when peer markets are also closed and out of step with orthodoxy (Simmons, 2000a; 2000b). In this environment, governments should anticipate that the use of outflow controls will do less harm to their market reputation.

If our argument is correct, the effect of CFV on outflow controls should be conditional on the use of controls in peer markets. CFV should not be associated with tighter outflow restrictions when peers are open since governments will fear that the loss of future investment due to reputational damage will be more costly to the economy than the temporary stabilizing benefits of controls. Conversely, CFV should lead governments to clamp down on outflows when peers have already tightened their capital accounts. In this context, governments should calculate that they can gain some stabilizing benefit of controls without damaging their market reputations, thereby avoiding reductions in future investment flows.

Analysis of twenty-five emerging markets' capital account policies from 1995 to 2015 supports our expectations. Consistent with existing research (Aizenman \& Pasricha, 2013), we find that governments are more likely to impose outflow controls as $\mathrm{CFV}$ increases. However, additional analyses reveal that this relationship is contingent on peer markets' policies. Following existing research, we construct three spatial lag variables designed to capture the extent of financial openness among a country's peers across three market categories: geography, financial market development, and sovereign ratings (Brooks et al., 2015). Across all three market peer categories, we find no systematic relationship between CFV and outflow controls when peers are open. However, when peer markets are already closed, the link between CFV and outflow controls is both substantively and statistically significant. 
Our study responds to calls in the field for researchers to expand our explanations of international economic policy choices beyond domestic-level variables (e.g., Oatley 2011, Kirshner 2010). Existing studies have done well to document the critical role domestic politics plays in influencing governments' capital account policy choices. We know, for instance, that capital controls are more likely to be used in countries with strong labor rights (Pond, 2018), those with left-wing governments (Brooks \& Kurtz, 2007; Kastner \& Rector, 2003), those that employ policies of financial repression, and those that have fixed exchange rates (Leblang, 1997). We also know that democratization appears to be associated with financial liberalization (Milner \& Mukherjee, 2009) and that as veto players increase, capital account policy is more stable (Kastner \& Rector, 2003). By considering how peer markets' policy choices constrain government decisions on financial policy, we contribute to scholarship seeking to better incorporate system-level, or sub-system level, variables into our theories and empirical models.

This study also contributes to a vast literature on reputation in world politics. While much work on the subject explores how reputations affect the way states are perceived by other actors in the international system and, in turn, how this influences outcomes across a range of issues (e.g., crisis bargaining, alliance commitments, sanctions, and sovereign debt) ${ }^{2}$ our work adds to a growing body of scholarship that explores how reputational concerns influence state behavior (Abbott \& Snidal, 2000; Chwieroth, 2013; Jensen et al., 2020; Simmons, 2000a; Terman \& Voeten, 2018; Walter, 2006; Weisiger \& Yarhi-Milo, 2015; Wolford, 2007). More narrowly, the findings contribute to our knowledge about the conditions under which governments are willing to use restrictions on capital outflows. Consistent with existing claims (Chwieroth, 2013; Erten et al., 2019), our analysis indicates that reputational considerations can constrain capital account policy choices in critical times. However, our findings present a more nuanced picture by showing that the intensity of reputational constraints varies with peer market policies.

\section{Reputational constraints and capital account policy}

Below we introduce our main argument in three stages. First, we explain why governments should be more likely to use outflow controls as CFV rises. Next, we discuss how reputational concerns constrain governments' capital account policy choices. Finally, we summarize why the use of controls among peer markets should affect the expected reputational costs of outflow controls.

\subsection{Capital flow volatility and outflow controls}

Since the volume of cross-border capital flows began increasing in the 1990s, flows have also become more volatile (IMF, 2011a). Volatile international capital flows pose risks to economic and financial stability in emerging markets. Capital inflow

\footnotetext{
${ }^{2}$ See Weisiger and Yarhi-Milo (2015) for a survey of this literature.
} 
surges (so-called capital flow bonanzas) have been linked to a range of destabilizing outcomes, including asset price bubbles, credit booms, banking crises, inflation, and rapid exchange rate appreciation (IMF 2011b; IMF 2012a; Kim and Yang 2011; Reinhart and Rogoff 2013). Yet perhaps the most concerning thing about inflow surges is that they eventually end-often abruptly (IMF, 2011b). In many cases, sudden stops and capital flow reversals follow bonanzas in emerging markets (Eichengreen and Gupta 2015; IMF 2011a). Such situations tend to be quite disruptive as they are associated with foreign exchange reserve depletion, currency crashes, asset price busts, the contraction of domestic credit, and slower economic growth (Calvo and Reinhart 1999; Edwards 2004; IMF 2012a). In addition, economic volatility and financial disruptions may reduce government popularity and undermine chances for political survival (Bernhard \& Leblang, 2008; Chwieroth \& Walter, 2019; Crespo-Tenorio et al., 2014; Pepinsky, 2012b; Quinn \& Woolley, 2001). Thus, when CFV rises, emerging market governments grow concerned about risks to macroeconomic stability. ${ }^{3}$

Governments have a suite of policy options they can employ to address problems related to CFV (López-Mejía, 1999). On the one hand, governments can use indirect macroeconomic measures, such as monetary policy, exchange rate, and fiscal policy adjustments. On the other, governments may also employ capital controls that directly affect cross-border financial flows. In recent years, emerging markets have shown greater interest in capital controls. This stems from concerns that indirect policy measures are not enough to mitigate risks from CFV as well as the political and structural constraints of such policy tools (Pradhan et al. 2011; Ghosh et al. 2017). ${ }^{4}$ Thus, our goal is to zoom in and focus on how reputational concerns mediate the link between CFV and outflow restrictions, controlling for other policy tools in our empirical analysis. ${ }^{5}$

As capital flows grow more volatile and the perceived costs of financial openness increase, governments should become more inclined to consider using restrictions on capital outflows to address risks from CFV. Numerous studies on emerging market responses to the global financial crisis support this conjecture, documenting how governments explicitly argued for greater freedom to use capital controls to reduce the deleterious effects of volatile global capital (Chwieroth 2010; Gallagher 2015; Grabel 2015; Grabel 2018). Consistent with these qualitative accounts, observational

\footnotetext{
${ }^{3}$ For example, in 2013, the governor of the Philippines' central bank openly worried about the Fed's plan to taper its bond-buying, stating that "the transition could prove to be thorny... As we have seen, volatile capital flows could expose [our] currency to instability." He also expressed concern about how CFV might affect inflation and thereby threaten "price and financial stability" (Montecillo, 2013).

${ }^{4}$ In the face of capital inflow surges, raising interest rates to address inflation may be politically unfeasible as it risks slowing the economy. Furthermore, in the absence of capital controls, a higher interest rate may attract more capital inflows, which can increase pressure for currency appreciation and hurt export competitiveness. Meanwhile, lowering interest rates to reduce currency appreciation pressures that follow massive capital inflows can protect export competitiveness but may lead to overheating.

${ }^{5}$ In this way, our approach is similar to recent studies that focus on capital controls and aim to explain governments' choices (Aizenman \& Pasricha, 2013; Fernández et al., 2015). For studies that seek to model emerging markets' different policy responses to volatile capital flows, see, e.g., Ghosh et al. (2017).
} 
studies have found that outflow controls are more common among emerging markets when capital flows are volatile (Aizenman \& Pasricha, 2013). Of course, none of this suggests that outflow controls are always the best, or even an appropriate, response to $\mathrm{CFV}$. Indeed, evidence on the effectiveness of outflow controls is mixed (IMF, 2012b). Our claim is simply that when facing volatile conditions, governments will, on average, grow more inclined to view outflow controls as a policy tool they can use to preempt capital flight and stabilize the macroeconomy. Thus, we expect that emerging market governments should be more likely to increase capital outflow restrictions as $C F V$ increases.

\subsection{Outflow controls and reputational costs}

Despite having motives to tighten restrictions on capital outflows in the face of volatility, emerging market governments also face countervailing reputational pressure to refrain from using such measures. The notion that controls on capital outflows present reputational consequences is widely discussed in academic and policy communities. Outflow controls have been described as "tantamount to default" (Ghosh et al. 2020) as they involve a "violation of explicit or implicit contracts" with investors in bond, equity, and other capital markets (Demirguc-Kunt \& Serven, 2009). ${ }^{6}$ Unsurprisingly, investors are highly critical of outflow controls as policy tools. For foreign investors, outflow controls deny them the ability to repatriate capital, resulting in financial losses. Residential investors, meanwhile, are denied the ability to safeguard their money by moving it abroad in times of crisis (Steinberg and Nelson 2019).

Indeed, for the past thirty years, the dominant view has been that outflow controls are not only ineffective (Magud et al., 2011; Edison \& Reinhart, 2001) but also "heterodox" policy tools that violate widely accepted norms related to property rights protection and the free cross-border flow of capital (Abdelal 2007; Chwieroth 2010; Edwards 1999). Consequently, governments worry that using outflow controls-even in critical times-will damage their market reputation resulting in lost investment now and into the future. As Chwieroth (2013) puts it, "emerging markets still generally fear that the use of controls will send a negative signal and harm their reputations with official and market actors."

In an environment of incomplete information, however, investors are unable to observe government policy preferences directly. They cannot know with certainty which governments, when facing CFV, are willing to resist using outflow controls by imposing macroeconomic adjustment policies and which governments will choose to employ outflow controls even though they harm investor interests. Due to this uncertainty, investors hold beliefs about each government's reputational "type" (Tomz, 2007). ${ }^{7}$ Broadly speaking, governments may develop orthodox reputations when

\footnotetext{
${ }^{6}$ While outflow controls are distinct from debt defaults in practice, each of these policy choices reflects a government's decision to alter policy in a way that adversely affects asset values.

${ }^{7}$ The argument presented by Tomz (2007) focuses on government reputation in sovereign debt markets, not capital controls. However, his reputational argument travels to this context given the similarity between
} 
investors are confident in policymakers' commitment to the free movement of capital. Alternatively, governments may earn heterodox reputations when investors doubt their commitment to financial openness. Without direct knowledge of a government's true preferences, investors observe current policy decisions to "infer the course of future policies" (Bartolini \& Drazen, 1997). When a government uses outflow controls, the decision not only diminishes the expected returns from onshore investment in the current period, it also sends a negative signal to investors about a government's future policy intentions. This harms the country's market reputation, reducing the expected returns from future onshore investment as well. As one World Bank study explains, outflow controls "raise the perceived riskiness of inward investment" and "this adverse effect may last well after the removal of the controls on outflows, as investors considering future capital inflows factor into their risk-return assessment an increased perception of the likelihood that they may be unable to take their capital out when needed, at least without cost" (Demirguc-Kunt \& Serven, 2009). Put more succinctly, Bartolini and Drazen (1997) explain that the "reputational effects [of outflow controls] could be long-lived."

This last point bears repeating. If using capital controls only diminished the investment attraction of a market for the period in which the measures were in place, governments would not be as reluctant to employ them. Policymakers could tradeoff a temporary reduction in market competitiveness for the stabilizing benefits of outflow controls in the face of CFV. Once the financial storm had passed, governments could remove outflow controls, and their economies would regain their appeal to investors. By considering the "stickiness" of a tarnished market reputation, our argument helps explain what appears to be a reluctance to use outflow controls. The cost-benefit analysis changes considerably when governments must weigh short-term stabilizing benefits of outflow controls against enduring reputational damage and reduced investment over the long-run.

Policy, practice, and empirical evidence back up our theoretical claims about reputational concerns related to outflow controls. For example, in remarks at an IMF conference in 2015, former Bank of Mexico Governor Agustín Carstens specifically warned an audience of emerging markets and developing countries against using outflow controls because they "present reputational effects." Carstens' conclusions align with past experience. Reviewing policy responses to the Asian Financial Crisis in 1997-98, one study explains that "Malaysia's reputation....was somewhat tarnished when the government imposed capital controls." Despite the temporary nature of the outflow controls, the authors note that the measures gave the "wrong impression that Malaysia's commitment to openness [had] changed when it [had] not" (Naya \& Plummer, 2005). Another study on the same case similarly concluded that the outflow restrictions "antagonized investors" and "damaged Malaysia's long-term reputation" (Fane, 2000). These statements are further supported by empirical research demonstrating that Malaysia's outflow controls caused a reduction in both short- and long-term capital flows that lasted long after restrictions were lifted (Goh, 2005).

sovereign default and outflow controls since they each violate, explicitly or implicitly, contracts with investors. 
To sum up, despite reasons to employ outflow controls in the face of increasing $\mathrm{CFV}$, governments also face countervailing reputational pressure to avoid tightening outflow restrictions. Any stabilizing benefits they may hope to achieve through the use of capital controls could be more than offset by reputational damage and reduced investment flows. And, while the effects of volatility may pass swiftly, their tarnished market reputation is unlikely to recover so quickly.

\subsection{Peer market policies and reputational costs}

Governments weigh the potential stabilizing benefits of using outflow controls against concerns of how their capital account policy decisions will affect their market reputations. In keeping with Tomz (2007), we contend that the anticipated reputational damage associated with the use of unorthodox policy tools is contingent on the broader economic context in which such policies are employed. ${ }^{8}$ The intensity of reputational damage associated with the use of outflow controls should be conditional on the use of such controls in a country's market peers. Recent work has shown that investor perceptions of peer market economies directly affect attitudes toward the investment climate in individual emerging and developing economies (Gray, 2013; Brooks et al., 2015). Brooks et al. (2015) explain how investors place individual countries into various country categories. Each category includes economies deemed to share similarities on specific market dimensions related to investment risk and opportunity. These categories, then, are used by investors as cognitive shortcuts when making decisions about where they will allocate assets. Such categorization defines the group of peer markets against which an individual country will be compared and against which it will compete for investment. From the perspective of an investor relying on such group-level heuristics, countries within the same category are likely to be viewed as close substitutes (Simmons \& Elkins, 2004).

When a country's market peers are using outflow controls, governments should anticipate that the reputational costs associated with heterodox measures decrease since the negative signal that outflow controls send to investors will be weakened. In this environment, as Simmons (2000a) explains, investors are likely to interpret the situation facing the country as "sufficiently dire" such that extreme measures are justified. She continues, "in a signaling framework, non-compliance in the context of generalized violation may not provide clear information on a country's future policy intentions." Put differently, when "everybody else is doing it," outflow controls do not provide as strong or lucid a signal to investors that a government's true type is heterodox. Additionally, in an environment where market substitutes are using outflow controls, policymakers should be less concerned about long-term investment losses from any potential lasting reputational damage. In this scenario, any lasting

\footnotetext{
${ }^{8}$ For Tomz (2007), the context that matters is not market peer policies, but rather whether a sovereign debt default occurs amid difficult economic circumstances-like a global interest rate shock-or whether default occurs during "good times." Such context provides additional information to investors about the government's reputational type. Reputational damage is severe when a government defaults during favorable economic times because it sends a strong signal that the government (a "lemon") has preferences counter to investor interests. However, governments that default amid adverse conditions ("fairweathers") send mixed signals about their true preferences, causing less harm to their reputation.
} 
reputational damage will be distributed across many countries within the peer group. Consequently, in the eyes of investors, the relative attractiveness of the home market compared to its market peers-both now and into the future-will not have shifted significantly. To again quote Simmons (2000b), "rampant violation by other governments...reduces the costs of non-compliance as investors find it more difficult to 'punish' any one violator."

On the other hand, when a country's market peers maintain open capital accounts, anticipated reputational costs associated with using outflow controls should be high. The logic here is the inverse of the above. In this environment, policymakers should worry that heterodox policy measures will stand out starkly against orthodox liberal peers, sending a strong and clear signal to investors that the government's future commitment to openness cannot be counted on. "The damage to one's reputation", Simmons (2000b) explains, "is amplified if the government is one of a handful of violators" in its grouping. ${ }^{9}$ Governments will also worry more about long-term investment losses stemming from a tarnished market reputation as peer markets retain their orthodox reputations. When a country implements policies that earn it a heterodox market reputation, investors will move their capital to markets "where they can do business more freely and securely" (Simmons \& Elkins, 2004). ${ }^{10}$ Moreover, because reputations are sticky, this competitive disadvantage is likely to outlast the period in which outflow controls are in place.

To summarize the full argument, as CFV increases, emerging market governments should be more likely to impose capital outflow controls in hopes of stabilizing the macroeconomy. However, given the negative signal that outflow controls send to investors about a government's future commitment to openness, policymakers' decisions to impose capital controls should be conditional on the perceived reputational costs associated with heterodox measures. When market peers are closed, and anticipated reputational costs of implementing new outflow controls are lower, emerging market governments should be more likely to view the stabilizing benefits of outflow controls as outweighing their reputational costs and, thus, be more likely to use the policy tool. Conversely, when market peers are open, and the perceived reputational costs of new outflow controls are high, governments should be less likely to increase capital account restrictions as the reputational costs outweigh the benefits. Put simply, we expect that emerging market governments should be more likely to increase capital outflow restrictions as CFV increases, but only when their peer economies' outflow restrictions are already high.

\footnotetext{
${ }^{9}$ This logic is entirely consistent with rating agency Fitch's decision to downgrade Malaysia's sovereign credit rating in 1998 after it imposed outflow restrictions during the Asian Financial Crisis. As Abdelal (2007) describes, "Fitch's analysts and managers...felt that the comparison with more orthodox neighbors cast Malaysia in a negative light, with the government 'imposing capital controls and rejecting the market discipline that has sped reforms in Korea and Thailand.",

${ }^{10}$ As Mosley (2000) puts it, when other markets have open capital accounts, investors' capacity to threaten "exit" is far more credible.
} 


\section{Testing the argument}

Here we present empirical evidence supporting our expectation that the link between $\mathrm{CFV}$ and outflow controls is contingent on peer markets' capital account policy choices.

\subsection{Data, models, and methods}

The outcome of interest We focus on a government's decision to tighten restrictions on capital outflows as our outcome of interest. In our analyses, we rely on new measures of capital account policy introduced by Fernández, Klein, Rebucci, Schindler, and Uribe (FKRSU, 2016). Similar to the widely used KAOPEN measure (Chinn \& Ito, 2006), the measures reflect de jure capital account policy based on the IMF's Annual Report on Exchange Arrangements and Exchange Restrictions. However, the new measures improve on KAOPEN in two key ways. First, they more accurately reflect annual changes in capital account policies. ${ }^{11}$ Second, they distinguish between controls on inflows and outflows, which allows for a disaggregated analysis essential for testing our argument. We rely on the KAO index from the dataset which accounts for the level of outflow controls. For our placebo tests, we use the KAI index which measures the level of inflow controls. The measures range from zero (open) to one (closed) and are available from 1995 through $2015 .{ }^{12}$

Key predictors Capital flow volatility (CFV) is the first of our key predictors in the analysis. To account for country-level CFV, we use quarterly ARIMA estimates of the standard deviation of net portfolio inflows provided by Pagliari and Hannan (2017). This measure improves upon existing measures of volatility in two main ways. First, by using finer-grained quarterly data, it provides a more accurate picture of volatility compared to existing measures that rely on annual data (Pagliari \& Hannan, 2017, 12-13). Second, recent analyses have shown that ARIMA estimates are superior to estimates from alternative approaches such as those based on a rolling-window (Broto et al., 2011; Pagliari \& Hannan, 2017). Specifically, measures under a rollingwindow approach lose observations at the beginning of the sample, depending on the size of the window. Additionally, such measures can generate problems of endogeneity, serial correlation, and overly smoothed estimates. Volatility estimates based on an ARIMA model have been shown to mitigate these problems. The ARIMA measure is available from the first quarter of 1970 through the first quarter of 2016 for 37 emerging markets and developing economies. To approximate annual volatility, we calculate the average ARIMA estimate across quarters within the same year. The

\footnotetext{
${ }^{11}$ See Karcher and Steinberg (2013) for a detailed discussion of this and other systematic measurement biases regarding KAOPEN.

${ }^{12}$ See Figure A.3 in the Online Appendix (available at the Review of International Organizations' webpage) for KAO trends for each of the twenty-five emerging markets in our study and their peer groups. See the left panel of Figure A.4 in the Online Appendix for the average trend among the emerging markets. Overall, recent trends have been generally U-shaped-decreasing before the global financial crisis but increasing since then.
} 


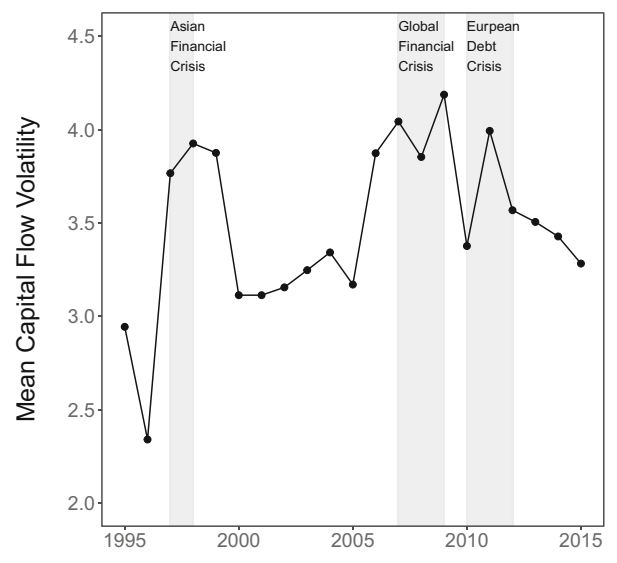

Fig. 1 Mean Capital Flow Volatility in Twenty-Five Emerging Markets, 1995-2015

ARIMA measure is highly skewed to the right, and thus we log-transform the measure in our analysis to reduce the influence of extreme values. Figure 1 shows that the average CFV among the twenty-five emerging markets in our sample has generally increased over time, with particular spikes consistent with economic crises. ${ }^{13}$

To account for peer markets' capital account policies, we construct three additional key predictors. We follow Brooks et al. (2015) in identifying the proper classifications for capital market peers. First, since investors often categorize countries into geographic groupings, we construct a Geographic Peers time-lagged spatial lag. Specifically, we calculate the weighted average of capital account restrictions in the previous year among members of a country's geographic reference group, with greater weights assigned to countries closer in their geographic distance. To measure geographic proximity, we rely on CEPII (2011)'s GeoDist dataset for dyadic distance data and calculate the inverse-square distance. ${ }^{14}$ Since geography is an immutable national characteristic, it is reasonable to assume that governments are aware of which countries qualify as their geographic peers.

Next, to account for a country's equity market peers, we create an $\mathrm{MSCl}$ Peers time-lagged spatial lag using the Morgan Stanley Capital International (MSCI) market classification index. This index accounts for the development and performance of countries' equity markets. MSCI divides countries into three categories: "Developed Markets," "Emerging Markets," and "Frontier Markets." MSCI also updates

\footnotetext{
${ }^{13}$ Figure A.5 in the Online Appendix illustrates ARIMA-based CFV trends for each of the emerging markets.

${ }^{14}$ More precisely, for each country $i$ in year $t$ we compute the time-lagged spatial lag $W_{i t}^{\top} Y_{t-1}^{*}$, where $W_{i t}^{\top}$ is an $N$ dimensional spatial weight vector whose $j$ th element represents the normalized inverse-square distance between country $i$ and $j$, and $Y_{t-1}^{*}$ is an $N$ dimensional vector that represents the level of capital account restrictions in each country in the previous year $t-1 . W_{i t}^{\top}$ does not vary over year $t$ as geographic distance does not change over time. Note that the use of time-lagged spatial lags is known to alleviate potential simultaneity biases that occur when estimating spatial OLS models (Beck et al., 2006; Franzese \& Hays, 2007; 2008).
} 
the countries included in each category annually and publishes this for public consumption. ${ }^{15}$ These decisions have significant implications for an economy's ability to attract foreign capital investment (Brooks et al., 2015). Thus, governments are highly likely to be aware of where MSCI places them and other countries on this list. To create this spatial lag, we calculate for each country and year the mean capital account restriction in the previous year of other countries that belong in the same MSCI category. Note that the list of countries in our sample includes those classified by MSCI as "Emerging Markets" and "Frontier Markets" but excludes countries classified as "Developed Markets." Thus, MSCI Peers varies across observations depending on the relevant reference category. ${ }^{16}$

Lastly, to account for a country's bond market peers, we construct a Ratings Peers time-lagged spatial lag based on sovereign credit ratings, specifically Fitch's Risk Rating index. Like other major credit rating agencies, Fitch's ratings (e.g., AAA, $\mathrm{AA}+$, etc.) reflect the agency's assessment of the probability that a government will default on its debts. Fitch determines the probability of default relying on a range of economic, political, and social factors in each rated country. Fitch's ratings are regularly updated and, like MSCI, the information is publicly available. ${ }^{17}$ Once again, it is safe to assume that governments are not only aware of their own sovereign rating but also know which countries are rated similarly. Following Brooks et al. (2015), we create this spatial lag by computing for each country and year the weighted average of capital account restrictions in the previous year among other countries in the same Fitch rating group. ${ }^{18}$

Figure A.1 in the Online Appendix shows, on average, positive but small withincountry correlations between the spatial lags. Such correlations suggest that our measures are capturing a similar latent concept. However, they also indicate that variation still exists across the measures depending on how we define market peers. Results that are consistent across the measures should thus increase our confidence in our findings. To guard against excessive model dependency and the potential lack of common support in the data, we bin each spatial lag by terciles (Hainmueller et al., 2019). Specifically, we set "high" levels of capital account restrictions among peers as the omitted baseline category and create two separate dummy variables that indicate "low" or "medium" levels. ${ }^{19}$ We include the interaction between CFV and these dummy variables in our empirical models to estimate the heterogeneous effect of volatility conditional on peers' capital restrictions.

\footnotetext{
${ }^{15} \mathrm{See}$ https://www.msci.com/market-classification.

${ }^{16}$ Specifically, $16 \%$ of our observations are classified as Frontier Markets, $64 \%$ as Emerging Markets, and the remainder are developing countries unclassified by MSCI. For the last group, we use the mean capital account restriction in the previous year for all other unclassified developing countries.

${ }^{17}$ See https://countryeconomy.com/ratings/fitch. Data indicate that Fitch's ratings during our study period are positive and highly correlated with ratings provided by other major credit rating agencies such as S\&P and Moodys'. See Figure A.2 in the Online Appendix.

${ }^{18}$ See Appendix S1 of Brooks et al. (2015) for their thirteen rating categories.

${ }^{19}$ We use data for all non-developed countries (as defined by MSCI) between 1995 and 2015 to calculate the terciles for each spatial lag.
} 
While our study focuses on the three peer categories explicitly identified in the literature (Brooks et al., 2015), we also explore partisanship (right, center, leftgovernment) as an additional peer category. ${ }^{20}$ That is, investors may compare the capital account policies of countries with the same government partisanship leaning. This implies that the level of partisanship peers' outflow restrictions may matter too. For example, while right-leaning governments tend to maintain lower levels of capital controls (Kastner \& Rector, 2003; Brooks \& Kurtz, 2007), it may be easier for them to implement capital controls when other right governments are doing the same. It is less clear, however, whether investors use government partisanship as a group-level heuristic to guide investment decisions in the same way they use the three common categories discussed above. Partisanship may be a weaker heuristic as information on parties and party platforms may be more limited in an emerging country context. To test the potential implications of partisanship peers, we construct a partisanship spatial lag by computing the weighted average of capital outflow restrictions in the previous year among members of an emerging markets partisanship reference group (right, center, left-government) using the "EXECRLC" variable in the Database of Political Institutions (Cruz et al., 2017). Overall, we do not find conclusive evidence in support of investors relying on this peer categorization, and we present the results and further discussions in Table B.5 in the Online Appendix.

Control covariates In addition to the key predictors, our models include a standard set of economic and political covariates that can affect CFV and also influence capital outflow controls. For economic covariates, we control for the size of the economy (the natural log of Gross Domestic Product, GDP) because larger emerging economies may attract more substantial capital flows, and such flows may also be more prone to sudden stops and reversals. Since developed economies are less likely to employ capital controls, we also account for the level of economic development (log of GDP per capita). Governments with liberal trade policies may also be less likely to restrict cross-border capital flows, so we control for trade openness (natural $\log$ of total trade as a \% of GDP). Because capital flows are highly sensitive to interest rate differentials and monetary policy represents an alternative policy option to address cross-border capital flows, we include Real Interest Rate in our models (Ahmed \& Zlate, 2014). We also account for the annual rate of Inflation in consumer prices. We rely on the World Bank's World Development Indicators database for data on the variables above. Lastly, because capital mobility complicates the maintenance of a fixed exchange rate, governments using an Exchange Rate Peg are more likely to employ capital controls. We thus account for countries that peg their currency using updated data from Shambaugh (2004).

For political covariates, we include a measure of Democracy based on "Polity" scores (Marshall et al., 2013) since existing studies have shown that regime type influences economic openness (Milner \& Mukherjee, 2009). To capture institutional constraints on capital account policy-making, we follow the literature (Kastner \&

\footnotetext{
${ }^{20} \mathrm{We}$ thank an anonymous reviewer for this suggestion.
} 
Rector, 2003; Mukherjee \& Singer, 2010; Brooks \& Kurtz, 2007) and control for Veto Players, which we measure using the "Checks" variable from the Database of Political Institutions (Cruz et al., 2017) as a proxy.

In a battery of robustness tests, we also control for Economic Crises and Partisanship. First, crises in a peer market may increase both volatility and outflow restrictions among countries in the same peer group. As a result, economic challenges that originated from peer countries might confound our findings. To account for this, we measured economic crises in three ways: whether a peer, in a given year, (1) experienced a speculative attack on its currency (Leblang, 2003), (2) participated in an IMF lending program (McDowell, 2017), or (3) experienced a banking crisis (Laeven \& Valencia, 2018). We then created three time-lagged spatial lags of each measure based on the corresponding peer group (geographic, MSCI, or ratings) and included them as additional controls in each respective model. Furthermore, we also include controls for economic crises in each emerging market country of focus. The inclusion of all these controls does not affect our main results. ${ }^{21}$

Second, extant research suggests that right-leaning governments are less likely to maintain high levels of capital controls (Quinn \& Inclán, 1997; Kastner \& Rector, 2003; 2005; Brooks \& Kurtz, 2007; Quinn \& Toyoda, 2007; Mukherjee \& Singer, 2010). Following this literature, we fit models that include a dummy variable that controls for the partisanship of the executive branch in emerging markets (Right/Center vs. left-government), which is drawn from the "EXECRLC" variable in DPI. Our focus on the partisanship of the executive branch instead of the legislature is preferable because capital account policy-making is mostly driven by executives (Brooks \& Kurtz, 2007, 710-711). It is important to note that when controlling for partisanship in emerging markets, a considerable number of substantively informative emerging markets (e.g., Indonesia and Malaysia) and emerging market country-years (e.g., Thailand, 2002-2015) drop from our sample due to missing data in DPI. ${ }^{22}$ Nevertheless, the inclusion of this partisanship control variable does not affect our main results even in the smaller sample. ${ }^{23}$

The universe of analysis Overall, we focus on twenty-five emerging markets that data exist for both capital outflow restrictions and CFV from 1995 through 2015. It is important to note that our empirical analysis starts in 1996 instead of 1995 as the time-lagged spatial lags require data on capital account restrictions in the previous year. In Online Appendix A.1, we provide a list of the emerging markets included in the analysis.

\footnotetext{
${ }^{21}$ For details of the models and estimates, see Table B.4 in the Online Appendix.

${ }^{22}$ As discussed in Cruz et al. (2017), the missingness is mainly due to either party platforms not focusing on economic issues, the existence of competing wings, or simply no information available.

${ }^{23}$ For details of these models and estimates accounting, see Table B.5 in the Online Appendix. Additionally, controlling for a dummy variable that captures post-communist countries in Europe and former Soviet Union countries does not affect our main results. See Table B.6 in the Online Appendix for details.
} 
Models and methods To test our argument, we fit a set of linear mixed-effects models:

$$
\begin{gathered}
y_{i t}=\alpha_{i}+\lambda_{t}+\beta x_{i t-1}+\gamma x_{i t-1} \psi_{i t}^{l o w}+\kappa x_{i t} \psi_{i t}^{m e d}+Z_{i t}+\epsilon_{i t} \\
\alpha_{i} \sim \mathrm{N}\left(\mu_{\alpha}, \sigma_{\alpha}^{2}\right), \quad \lambda_{t} \sim \mathrm{N}\left(\mu_{\lambda}, \sigma_{t}^{2}\right), \quad \epsilon_{i t} \sim \mathrm{N}\left(0, \sigma_{y}^{2}\right)
\end{gathered}
$$

where $y_{i t}$ represents the outcome of interest capital outflow restrictions (KAO). The variable $x_{i t-1}$ indicates the log-transformed ARIMA measure of capital flow volatility while $\psi_{i t}$ represents time-lagged spatial lags (e.g., Geographic Peers). The key quantity of interest is $\beta$ which represents the baseline effect of volatility when peers' capital account restrictions are high (i.e., when both $\psi_{i t}^{\text {low }}=0$ and $\psi_{i t}^{\text {med }}=0$ ). The variables $\boldsymbol{Z}_{i t-1}$ include potential confounding covariates discussed above. We lag CFV and control variables by one year to account for the possibility of reverse causality. The variables $\alpha_{i}$ and $\lambda_{t}$ denote varying intercepts for countries and years, respectively. Note that, under a mixed-effects model, one assumes that these intercepts follow some distribution with their mean $\left(\mu_{\alpha}\right.$ and $\left.\mu_{\lambda}\right)$ and standard deviation $\left(\sigma_{\alpha}^{2}\right.$ and $\left.\sigma_{t}^{2}\right)$ estimated from the data. This approach enables the estimation of $\beta$ with smaller variance by partially pooling information across units or time (Gelman \& Hill, 2007). In contrast, fixed effects models assume independent intercepts with $\sigma_{\alpha}^{2} \rightarrow \infty$ and $\sigma_{t}^{2} \rightarrow \infty$ which disregards such group-level information and yields estimates with higher variance. Overall, we show in Appendix B that results from fixed-effects models with clustered standard errors (Table B.2) are substantively similar to that of our main mixed-effects model (Table B.1).

We fit four different models based on the model specification above. In our baseline model, we omit the interaction terms. In other words, we examine the relationship between volatility and capital outflow restrictions regardless of the level of restrictions among peers. In the next three models, we augment the baseline model with the interaction terms for Geographic Peers, MSCI Peers, and Ratings Peers, respectively. These models allow us to separate the effect of volatility at different levels of restrictions among peers.

\subsection{Main results}

Consistent with our argument, results from the baseline model show a positive correlation between CFV and capital outflow restrictions in emerging markets. Specifically, column (5) of Table B.1 in the Online Appendix indicates that a one-unit increase in log volatility increases capital outflow restrictions in emerging markets by around 0.03 units. These results are consistent with studies that find that increasing CFV to be associated with outflow controls (Aizenman \& Pasricha, 2013). ${ }^{24}$ However, results from our interaction models show that the positive correlation between CFV and capital outflow restrictions stems mainly from periods when peers' capital outflow restrictions are high. Figure 2 summarizes the estimated results when conditioning on different levels of outflow restrictions among Geographic Peers (left),

\footnotetext{
${ }^{24}$ The results are also similar to Pepinsky (2012a) who shows that currency crises - a consequence of $\mathrm{CFV}$-lead governments to increase capital controls.
} 


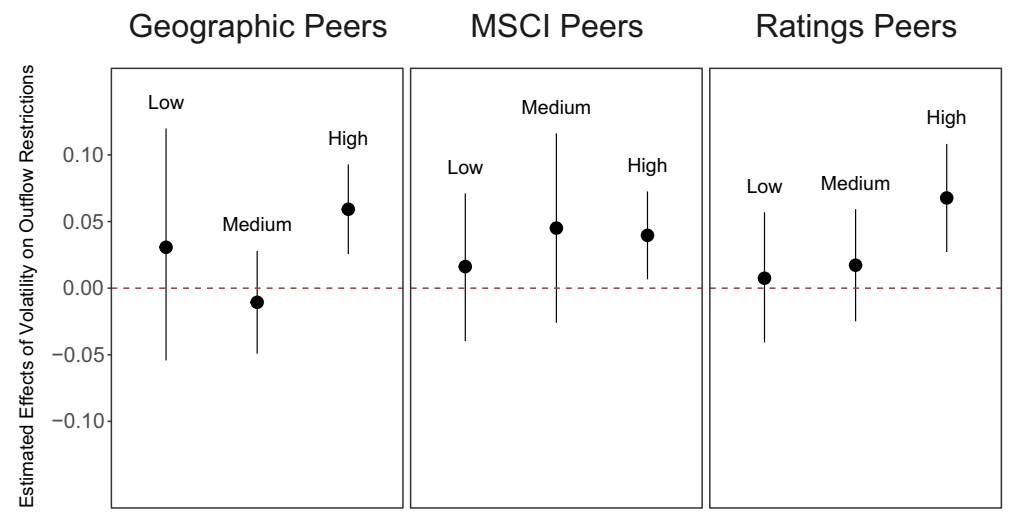

Fig. 2 The Heterogeneous Effects of Capital Flow Volatility on Outflow Restrictions. This figure shows that the positive effect of volatility on outflow restrictions exists only when market peers have high levels of outflow restrictions. The figure presents linear mixed effects point-estimates and $95 \%$ confidence intervals. Bins are based on terciles

MSCI Peers (middle), and Ratings Peers (right), respectively. ${ }^{25}$ The results in the left panel show that the relationship between $\mathrm{CFV}$ and outflow restrictions is mixed and statistically indistinguishable from zero when outflow restrictions among geographic peers are at low or medium levels. Yet when outflow restrictions among geographic peers are high, a one-unit increase in log volatility increases capital outflow restrictions by around 0.06 , which is approximately double the size of the effect in the baseline model. Similarly, the results in the middle and right panel both show null effects when outflow restrictions among MSCI or Ratings peers are at low or medium levels. Conversely, when outflow restrictions among MSCI or Ratings peers are high, a one-unit increase in log volatility increases capital outflow restrictions by around 0.04 or 0.07 units, respectively.

To help gauge the substantive magnitude of these effects, Online Appendix C shows how predicted levels of outflow restrictions change as volatility increases under the scenario of high outflow restrictions among market peers. Overall, the results suggest that increasing volatility from one standard deviation below the mean to one standard deviation above increases outflow restrictions by around 0.07 to 0.12 units. How big is this effect in substantive terms? For a typical emerging market with a mean outflow restriction of 0.53 (e.g., Chile), it represents a 13 to $23 \%$ increase in restrictions. Given that one standard deviation in outflow restrictions in our sample is 0.39 , it also represents an effect size of 0.18 to 0.3 standard deviations of the outcome. In comparison, the effect of increasing an emerging market's GDP per capita-traditionally one of the strongest predictors of capital controls - from one standard deviation below the mean to above reduces outflow restrictions by around 0.61 units. Hence, when peer outflow restrictions are high, the effect of volatility is approximately 11 to $20 \%$ of the effect of GDP per capita.

\footnotetext{
${ }^{25}$ Table B. 1 in the Online Appendix presents model estimates.
} 
Lastly, we find even stronger results when fitting the above models to an outcome measure that excludes outflow restrictions on long-term capital investments less relevant to our argument. Our argument about outflow controls relates primarily to short-term portfolio investments rather than longer-term capital flows like foreign direct investment (FDI). Additionally, research indicates that peer country categories, while important for portfolio capital flows, may not matter as much for long-term investment categories (Linsi \& Schaffner, 2019). Consequently, we excluded from the construction of the KAO index any restrictions on direct investment outflows (DIO) and real estate outflows (REO). We then used this measure of short-term capital outflow restrictions (KAO short) as the outcome in the models. We find that the effect of volatility when peers' restrictions are high is statistically significant and larger in magnitude (see the first row of Table B.3 in the Online Appendix). Meanwhile, the effects of volatility were, again, null when peers' restrictions were at low or medium levels.

Together, these results support our expectation that as CFV increases, emerging market governments are more likely to tighten restrictions on capital outflows, but only when market peers have already employed heterodox measures. Conversely, capital account policy appears constrained when market peers maintain liberal, orthodox policies. In this environment, governments refrain from using outflow controls when facing CFV. The results are consistent with our argument that reputational considerations play a meaningful role in dictating whether emerging markets impose restrictions on capital outflows in response to destabilizing cross-border capital flows.

\subsection{Robustness tests}

To further probe the robustness of our findings, we first conduct two sets of placebo tests and then investigate empirical support for alternative explanations.

Placebo moderating variables One of our central claims is that capital outflow policies of peer markets are the key reference point for governments weighing the reputational costs of using outflow controls. Relative to non-peer markets, investors are more likely to compare a government's reputation for openness against peer economies when deciding where to allocate assets. If we are correct, then non-peer reference points should have little moderating effects on the relationship between CFV and outflow controls.

To test this, we employ two alternative reference points. First, we consider the average global level of outflow controls. Our findings based on a peer market variable may be merely picking up on broader global patterns in the use of outflow controls. In this case, the moderating effect of peer policies would be epiphenomenal to general international trends. Second, we consider the use of outflow controls among the world's fastest-growing economies since existing analyses show that the use of controls among this group can influence foreign capital account policy choices (Simmons \& Elkins, 2004). Movement in either of these non-peer reference points may have reputational effects on the use of outflow controls. For example, when outflow controls are more common globally or among the world's best performing 


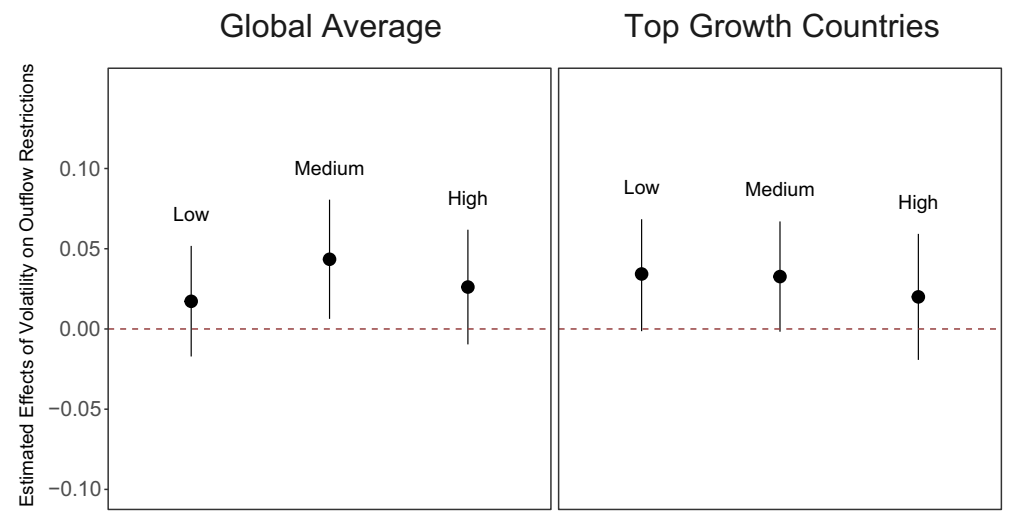

Fig. 3 Estimated Effects: Placebo Moderators. This figure shows the null effects of capital flow volatility on emerging market's capital outflow restrictions when the average level of such restrictions are high globally or among top growth countries. The figure presents linear mixed effects point-estimates and $95 \%$ confidence intervals. Bins are based on terciles

economies, emerging markets may adjust their expectations about reputational costs and become more inclined to use outflow controls in the face of CFV. However, if peer market policy is the more relevant benchmark for generating reputational costs, and investors tend to draw comparisons within such narrower categories (Brooks et al., 2015), then the potential reputational effects of these non-peer reference points should be less pronounced. In particular, the reputational costs of emerging markets deviating from the global average or the use among successful economies should be less severe compared to deviating from the use among their direct peers. Meanwhile, the use of outflow controls among direct peers should provide stronger protection against reputational damage than the use among non-peer groups. As a result, observing a moderating effect by these non-peer reference points should be less likely. To conduct the tests, we fit the same set of models in equation (1) but use the mean global level of KAO in the previous year and the mean level of KAO in the previous year among the fastest-growing economies (top decile) as placebo moderators in place of our peer market spatial lags. ${ }^{26}$

We find no evidence that the capital account policies of non-peers moderate the link between CFV and restrictions on outflows in ways consistent with our reputational argument. Figure 3 shows that the association between CFV and outflow controls is relatively small and statistically indistinguishable from zero when the global use of controls is high. Similarly, the association between CFV and KAO is also small and imprecisely estimated even when fast-growing countries have high levels of outflow controls. These findings contrast with our main results. They suggest that our findings based on peer market policies are not simply picking up on the use of outflow controls more generally or among fast-growing economies. Rather, there is something uniquely important about the moderating effect of peer market

\footnotetext{
${ }^{26}$ See Figure A.4 in the Online Appendix for these trends.
} 
policies on how governments calculate the reputational costs of outflow controls in different contexts.

Placebo outcome variable Like outflow controls, restrictions on capital inflow can temporarily diminish an economy's attractiveness as they reduce expected returns from onshore investment. Yet, unlike outflow controls, measures regulating inflows do not generate reputational costs. Because they are imposed before investment, rather than ex post, inflow restrictions do not violate implicit or explicit contracts with investors the way outflow restrictions do (Ghosh et al., 2020). Studies on investor attitudes toward capital controls echo this point. While the use of outflow controls was consistently met with opprobrium in the 1990s and 2000s, inflow controls were viewed with greater nuance, understood as an occasionally useful policy tool (Chwieroth 2010; Forbes 2007, 172). Moreover, since the 2008 financial crisis, inflow controls have been further legitimized as valuable, if temporary, measures for countries facing destabilizing cross-border capital flows (Chwieroth, 2014). As a result, employing inflow controls should not send a "heterodox" signal that harms a government's market reputation. If our argument is correct, then peer market policy contexts should not affect government decisions to impose inflow controls the way they do for outflow controls since the reputational effects are present only in the latter case. To assess this, we again fit the same set of models in equation (1), this time substituting $\mathrm{KAI}$ - a measure of inflow controls—as a placebo outcome for KAO.

We find no evidence that peer market policies influence emerging market government decisions to employ capital inflow restrictions in the face of CFV. In contrast to our main findings, Figure 4 shows that, even when the level of peers' inflow restrictions are high, the point estimates associated with the effect of CFV on inflow controls are generally small and statistically indistinguishable from zero. Furthermore, these findings persist across all three types of market peers. These differences between the placebo outcome results and our main analysis are notable given that

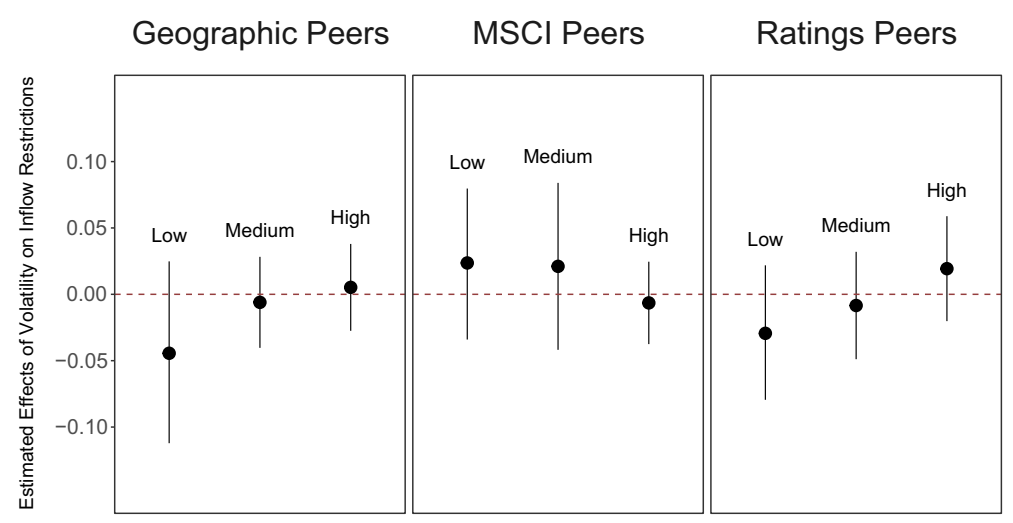

Fig. 4 Estimated Effects: Capital Inflow Restrictions as a Placebo Outcome. This figure shows the null effects of capital flow volatility on emerging market's capital inflow restrictions even when capital inflow restrictions among peers are high. The figure presents linear mixed effects point-estimates and $95 \%$ confidence intervals. Bins are based on terciles 
government inflow and outflow restrictions tend to be highly correlated with one another (Pond, 2018). In addition, the results suggest that our findings on outflow restrictions are unlikely due to chance alone or an artifact of how CFV affects capital restrictions in general. Instead, the placebo tests show that the effects of CFV are endemic to when peers' outflow restrictions are high, which is uniquely linked to concerns about market reputation.

Alternative mechanisms One alternative explanation for our main results is that they may simply be driven by short-term competition for capital instead of longer-term reputational concerns. That is, governments refrain from using outflow controls when peers are open not because they worry about sending heterodox signals to investors that can damage their market reputation but because they do not want to lose out on investments while the policies are in place. In other words, a simple competitionbased mechanism may be able to explain our results without invoking reputation.

To assess empirical support for the different explanations, we explore whether the effect of CFV, when peers are open, varies by the amount of liquidity in global capital markets. When interest rates on safe assets are low, global capital tends to be plentiful, and research has shown that investors are less critical of domestic policy environments during such periods (Ballard-Rosa et al., 2021). The logic is straightforward: When the return on safe assets is negligible, investors become less discerning and more risk-tolerant. Thus, short-term competitive pressures will be diminished in times of abundant global capital as investors are willing to overlook otherwise distasteful policy measures, like outflow controls.

A pure competition explanation void of long-term reputational concerns would predict that during periods of plentiful liquidity, government policy space is freed up as investors become more risk-tolerant. As competitive pressures decline, peer market policies should become less of a constraint on governments' choices. Thus, we should observe a consistent positive effect of CFV on outflow controlseven when peer markets are open. Alternatively, if our reputational mechanism is correct, in times of abundant global capital, liberal peers should still constrain governments facing CFV from using outflow controls. Because a tarnished market reputation is sticky, using outflow controls presents lasting effects on investor perceptions of an economy's attractiveness as an investment destination. While outflow controls may do little to reduce investment in the current period of abundant capital, governments should still worry that a heterodox reputation will have deleterious effects on investment flows as global liquidity dries up in future periods.

We test these different predictions by fitting a set of models similar to those in equation (1) but further interacting CFV and peer policies with a measure of global capital liquidity. Following Ballard-Rosa et al. (2021) and Oatley et al. (2013), we adopt U.S. Interest Rates as a proxy for global capital abundance. ${ }^{27}$ Again, we bin the variable into "low" versus "high" levels to guard against excessive model dependency and the potential lack of common support (Hainmueller et al., 2019). Low levels

\footnotetext{
${ }^{27}$ Specifically, an annual measure of the Effective Fed. Funds Rate (Federal Reserve Bank of St. Louis, 2021a).
} 
indicate minimal returns on safe assets, suggesting abundant global capital, while high levels indicate higher returns corresponding to periods of scarce global capital. ${ }^{28}$

Overall, we find little empirical support for a pure competition explanation void of reputational concerns. In particular, when global capital is abundant and peers' markets are open, the point estimates associated with the effect of CFV on outflow controls are generally small and statistically indistinguishable from zero across models. ${ }^{29}$ This indicates that even when global capital markets are flush, peer market policies still have a moderating effect on the link between CFV and outflow controls, constraining government policy choices. Furthermore, holding constant peer openness, we find no statistically distinguishable difference in the effect of CFV when global capital is abundant or scarce. ${ }^{30}$ Given (1) null effects of CFV even when global capital is abundant, and (2) the absence of a notable difference in the effect of CFV between global liquidity contexts, the results provide further empirical evidence that our main findings are more consistent with an explanation based on lasting reputational concerns than short-term competitive pressures alone. ${ }^{31}$

\section{Concluding remarks}

As the global financial system has become more integrated over the last thirty years, volatile international capital flows have become a significant threat to the health and stability of emerging market economies. As a result, many governments maintain that they need more policy space to mitigate such risks. The use of restrictions on outflows of capital is an instrument policymakers contend should be at their disposal when facing capital flow volatility (CFV). However, the potential benefits of clamping down on outflows in times of volatility may be offset by anticipated reputational costs. Governments worry that the use of a heterodox policy tool could do lasting damage to their market reputation by sending a negative signal to investors about their future commitment to openness, leading to diminished investment flows in the short- and long-term.

We propose that the anticipated effect of outflow controls on a country's market reputation is contingent on the use of similar measures in peer markets. When market peers have adopted liberal policies, governments worry that employing illiberal measures will send a strong and clear negative signal to investors that its true preferences are heterodox, reducing the attractiveness of the economy to investors

\footnotetext{
${ }^{28}$ See Table B. 8 in the Online Appendix for details of the full model specification and estimates.

${ }^{29}$ See row (1) of Table B.8 in the Online Appendix.

${ }^{30}$ For example, see row (15) of Table B.8 in the Online Appendix.

${ }^{31}$ As robustness tests, we conduct similar analyses but replace the Effective Federal Fund Rate with (1) the Wu-Xia Shadow Federal Funds Rate (Federal Reserve Bank of Atlanta, 2021), which better accounts for "zero lower-bound" environments and times of unconventional monetary policy by the Federal Reserve, and (2) the VIX index (Federal Reserve Bank of St. Louis, 2021b), which captures investors' perceptions about global market risk. We find that the $\mathrm{Wu}$-Xia shadow rate produces exactly the same results compared to those using the Effective Federal Funds Rate since the two measures are identical when dichotomized. Additionally, we find that the VIX index yields substantively similar results (see Table B.9 in the Online Appendix).
} 
in the present and future periods-even after the outflow measures are removed. On the other hand, when peers have clamped down on capital outflows, capital account restrictions do not send as strong a signal to investors about a country's future commitment to liberalism. Thus, policymakers should expect that any damage to the country's market reputation and potential for reduced investment flows will be significantly reduced. If reputational concerns do constrain capital account policy in emerging markets, we should see a strong positive association between CFV and outflow controls-but only when peers market competitors are already restricting outflows.

Our empirical analysis supports these expectations. First, our base model indicates that for our sample of emerging market economies, CFV is associated with an increase in capital outflow controls, consistent with existing research (Aizenman \& Pasricha, 2013). However, additional analyses reveal that this effect is conditional on the level of controls in peer market economies. Regardless of the peer category we use, there is no relationship between CFV and outflow controls when market competitors' have adopted liberal policies. However, when market peers' capital outflow controls are highly restrictive, the link between CFV and outflow controls is substantively and statistically significant. The results are robust to more narrow definitions of capital outflow controls, placebo outcome and moderating variables, and accounting for the global liquidity environment.

One limitation of our argument is that it cannot explain why a market peer would be the first to move away from financial openness at a given point in time. Much like existing studies on policy diffusion, the cause of the first mover in this policy space is exogenous to our theory. Considerable existing work-much of it cited in this study-identifies a range of other domestic and international forces that push governments' capital account policy in one direction or the other. Thus we acknowledge that these other factors are better suited to explain initial deviations from a peer group's status quo. Yet, our analysis indicates that once the status quo begins to shift, it can exert an independent effect on policymakers' cost-benefit calculations by intensifying or mollifying reputational concerns.

Our study responds to the challenge from Oatley (2011) for scholars of political economy to do more to incorporate the international context into our theories and our empirical models (e.g Steinberg et al. 2020). We show that reputational constraints on governments' economic policy choices cannot be understood in isolation. Instead, they depend on the international policy context in which they are situated. So, while our findings are broadly consistent with the argument that the anticipated reputational consequences associated with the use of outflow controls constrain governments' financial policy choices (Erten et al., 2019; Chwieroth, 2013), they also present a more nuanced picture by revealing that perceived reputational consequences are not a constant, but rather a variable.

This study also contributes to existing work showing how reputational considerations shape and constrain state behavior (Abbott \& Snidal, 2000; Jensen et al., 2020; Simmons, 2000a; Terman \& Voeten, 2018; Walter, 2006; Weisiger \& Yarhi-Milo, 2015; Wolford, 2007). Building on the studies of others who model how government policy choices work as signals to investors operating in environments characterized by incomplete information (Bartolini \& Drazen, 1997; Ghosh et al., 2020; Tomz, 
2007), our analysis supports an expanding body of scholarship showing that reputational concerns do in fact limit governments' economic policy autonomy (Andone \& Scheubel, 2017; Chwieroth, 2013; Ito, 2012). Governments appear to refrain from using heterodox policies-even during critical times-if expected reputational costs are high. Conversely, our analysis also indicates that policy space can be freed up when multiple countries clustered in relevant market peer categories adopt heterodox measures together. When it comes to avoiding reputational costs of outflow controls, there appears to be safety-and freedom—in numbers.

Supplementary Information The online version contains supplementary material available at https://doi.org/10.1007/s11558-021-09433-1.

\section{References}

Abbott, K. W., \& Snidal, D. (2000). Hard and Soft Law in International Governance. International Organization, 54(3), 421-456.

Abdelal, R. (2007). Capital Rules: The Construction of Global Finance. Cambridge, MA: Harvard University Press.

Ahmed, S., \& Zlate, A. (2014). Capital Flows to Emerging Market Economies: A Brave New World?. Journal of International Money and Finance, 48, 221-248.

Aizenman, J., \& Pasricha, G. K. (2013). Why Do Emerging Markets Liberalize Capital Outflow Controls? Fiscal Versus Net Capital Flow Concerns. Journal of International Money and Finance, 39, $28-64$.

Andone, I., \& Scheubel, B. (2017). Memorable Encounters? Own and Neighbours' Experience with IMF Conditionality and IMF Stigma. CESifo Working Paper. Available at https://ideas.repec.org/p/ces/ ceswps/_6399.html.

Ballard-Rosa, C., Mosley, L., \& Wellhausen, R.L. (2021). Contingent Advantage? Sovereign Borrowing, Democratic Institutions and Global Capital Cycles. British Journal of Political Science, 51(1), 353373.

Bartolini, L., \& Drazen, A. (1997). Capital-Account Liberalization as a Signal. American Economic Review, 87(1), 138-154.

Beck, N., Gleditsch, K. S., \& Beardsley, K. (2006). Space Is More than Geography: Using Spatial Econometrics in the Study of Political Economy. International Studies Quarterly, 50(1), $27-44$.

Bernhard, W., \& Leblang, D. A. (2008). Cabinet Collapses and Currency Crashes. Political Research Quarterly, 61(3), 517-531.

Brooks, S. M., Cunha, R., \& Mosley, L. (2015). Categories, Creditworthiness, and Contagion: How Investors' Shortcuts Affect Sovereign Debt Markets. International Studies Quarterly, 59(3), 587-601.

Brooks, S. M., \& Kurtz, M. J. (2007). Capital, Trade, and the Political Economies of Reform. American Journal of Political Science, 51(4), 703-720.

Broto, C., Díaz-Cassou, J., \& Erce, A. (2011). Measuring and Explaining the Volatility of Capital Flows to Emerging Countries. Journal of Banking \& Finance, 35(8), 1941-1953.

CEPII (2011). The GeoDist Database. Available at http://www.cepii.fr/anglaisgraph/bdd/distances.htm.

Calvo, G. A., \& Reinhart, C. (1999). Capital Flow Reversals, the Exchange Rate Debate, and Dollarization. Finance \& Development, 36(3), 13-15.

Chinn, M. D., \& Ito, H. (2006). What Matters for Financial Development? Capital Controls, Institutions, and Interactions. Journal of Development Economics, 81(1), 163-192.

Chwieroth, J. M. (2010). Capital Ideas: The IMF and the Rise of Financial Liberalization. Princeton, NJ: Princeton University Press.

Chwieroth, J. M. (2013). Creating Policy Stigmas in Financial Governance: The International Monetary Fund and Capital Controls. In D. G. Mayes, \& G. Wood (Eds.) Reforming the Governance of the Financial Sector (pp. 189-219). London: Routledge.

Chwieroth, J. M. (2014). Controlling Capital: The International Monetary Fund and Transformative Incremental Change from Within International Organisations. New Political Economy, 19(3), 445-469. 
Chwieroth, J. M., \& Walter, A. (2019). The Wealth Effect: How the Great Expectations of the Middle Class Have Changed the Politics of Banking Crises. Cambridge: Cambridge University Press.

Crespo-Tenorio, A., Jensen, N. M., \& Rosas, G. (2014). Political Liabilities: Surviving Banking Crises. Comparative Political Studies, 47(7), 1047-1074.

Cruz, C., Keefer, P., \& Scartascini, C. (2017). Database of Political Institutions 2017. Available at https:// publications.iadb.org/en/database-political-institutions-2017-dpi2017.

Demirguc-Kunt, A., \& Serven, L. (2009). Are All the Sacred Cows Dead? Implications of the Financial Crisis for Macro and Financial Policies. World Bank Policy Research Working Paper. Available at http://documents.worldbank.org/curated/en/100541468157778616/pdf/WPS4807.pdf.

Edison, H., \& Reinhart, C. M. (2001). Stopping Hot Money. Journal of Development Economics, 66(2), 533-553.

Edwards, S. (1999). How Effective are Capital Controls?. Journal of Economic Perspectives, 13(4), 65-84.

Edwards, S. (2004). Financial Openness, Sudden Stops, and Current-Account Reversals. The American Economic Review, 94(2), 59-64.

Eichengreen, B., \& Gupta, P. (2015). Tapering Talk: The Impact of Expectations of Reduced Federal Reserve Security Purchases on Emerging Markets. Emerging Markets Review, 25, 1-15.

Erten, B., Korinek, A., \& Ocampo, J.A. (2019). Capital Controls: Theory and Evidence. NBER Working Paper. Available at http://www.nber.org/papers/w26447.

Fane, G. (2000). Capital Mobility, Exchange Rates, and Economic Crises. Edward Elgar Publishing.

Federal Reserve Bank of Atlanta (2021). Wu-Xia Shadow Federal Funds Rate. Available at https://www. frbatlanta.org/cqer/research/wu-xia-shadow-federal-funds-rate.

Federal Reserve Bank of St. Louis (2021a). Effective Federal Funds Rate. Available at https://fred. stlouisfed.org/series/FEDFUNDS.

Federal Reserve Bank of St. Louis (2021b). CBOE Volatility Index: VIX. Available at https://fred. stlouisfed.org/series/VIXCLS.

Fernández, A., Klein, M. W., Rebucci, A., Schindler, M., \& Uribe, M. (2016). Capital Control Measures: A New Dataset. IMF Working Paper. Available at https:/www.imf.org/en/Publications/WP/Issues/ 2016/12/31/Capital-Control-Measures-A-New-Dataset-42867.

Fernández, A., Rebucci, A., \& Uribe, M. (2015). Are Capital Controls Countercyclical?. Journal of Monetary Economics, 76, 1-14.

Financial Times (2020). Letter: The Threat is Greatest for Developing and Emerging Countries. In Financial Times. Available at https://www.ft.com/content/35053854-6d17-11ea-89df-41bea055720b.

Forbes, K. J. (2007). The Microeconomic Evidence on Capital Controls: No Free Lunch. In S. Edwards (Ed.) Capital Controls and Capital Flows in Emerging Economies: Policies, Practices, and Consequences (pp. 171-202). Chicago: University of Chicago Press.

Franzese, R. J., \& Hays, J. C. (2007). Spatial Econometric Models of Cross-Sectional Interdependence in Political Science Panel and Time-Series-Cross-Section Data. Political Analysis, 15(2), 140-164.

Franzese, R. J., \& Hays, J. C. (2008). Interdependence in Comparative Politics: Substance, Theory, Empirics, Substance. Comparative Political Studies, 41(4-5), 742-780.

Gallagher, K. P. (2015). Contesting the Governance of Capital Flows at the IMF. Governance, 28(2), 185-198.

Gelman, A., \& Hill, J. (2007). Data Analysis Using Regression and Multilevel/Hierarchical Models. New York, New York Cambridge University Press.

Ghosh, A. R., Kim, J. I., \& Qureshi, M.S. (2020). What's In a Name? That Which We Call Capital Controls. Economic Policy, 35(101), 147-208.

Ghosh, A. R., Ostry, J. D., \& Qureshi, M.S. (2017). Managing the Tide: How Do Emerging Markets Respond to Capital Flows?. IMF Working Paper. Available at https://www.imf.org/en/Publications/WP/ Issues/2017/03/27/Managing-the-Tide-How-Do-Emerging-Markets-Respond-to-Capital-Flows-44766.

Goh, S. K. (2005). New Empirical Evidence on the Effects of Capital Controls on Composition of Capital Flows in Malaysia. Applied Economics, 37(13), 1491-1503.

Grabel, I. (2015). The Rebranding of Capital Controls in An Era of Productive Incoherence. Review of International Political Economy, 22(1), 7-43.

Grabel, I. (2018). When Things Don't Fall Apart: Global Financial Governance and Developmental Finance in an Age of Productive Incoherence. Cambridge, MA: The MIT Press.

Gray, J. (2013). The Company States Keep: International Economic Organizations and Investor Perceptions. Cambridge: Cambridge University Press. 
Hainmueller, J., Mummolo, J., \& Xu, Y. (2019). How Much Should We Trust Estimates from Multiplicative Interaction Models? Simple Tools to Improve Empirical Practice. Political Analysis, 27(2), 163-192.

IMF (2011a). The Multilateral Aspects of Policies Affecting Capital Flows. IMF Background Paper. Available at http://www.imf.org/external/np/pp/eng/2011/102111.pdf.

IMF (2011b). Recent Experiences in Managing Capital Inflows: Cross-Cutting Themes and Possible Policy Framework. IMF Working Paper. Available at http://www.imf.org/external/np/pp/eng/2011/ 021411a.pdf.

IMF (2012a). The Liberalization and the Management of Capital Flows: An Institutional View. Policy Papers. Available at http://www.imf.org/external/np/pp/eng/2012/111412.pdf.

IMF (2012b). Background Paper: Liberalizing Capital Flows and Managing Outflows. Policy Papers, 8(02), 266. Available at https://www.imf.org/ /media/Websites/IMF/imported-full-text-pdf/external/ np/pp/eng/2012/_031612.ashx.

Ito, T. (2012). Can Asia Overcome the IMF Stigma?. The American Economic Review, 102(3), 198-202.

Jensen, N. M., Johnston, N. P., Lee, C., \& Sahin, H. (2020). Crisis and Contract Breach: The Domestic and International Determinants of Expropriation. Review of International Organizations, 15, 869-898.

Karcher, S., \& Steinberg, D. A. (2013). Assessing the Causes of Capital Account Liberalization: How Measurement Matters. International Studies Quarterly, 57(1), 128-137.

Kastner, S. L., \& Rector, C. (2003). International Regimes, Domestic Veto-Players, and Capital Controls Policy Stability. International Studies Quarterly, 47(1), 1-22.

Kastner, S. L., \& Rector, C. (2005). Partisanship and the Path to Financial Openness. Comparative Political Studies, 38(5), 484-506.

Kim, S., \& Yang, D. Y. (2011). The Impact of Capital Inflows on Asset Prices in Emerging Asian Economies: Is Too Much Money Chasing Too Little Good?. Open Economies Review, 22(2), 293-315.

Kirshner, J. (2010). The Second Crisis in IPE Theory. In N. Phillips, \& C. E. Weaver (Eds.) International Political Economy: Debating the Past, Present, and Future (pp. 203-209). New York: Routledge.

Laeven, L., \& Valencia, F. (2018). Systemic Banking Crises Revisited. IMF Working Paper. Available at https://www.imf.org/en/Publications/WP/Issues/2018/09/14/Systemic-Banking-Crises-Revisited-46232.

Leblang, D. A. (1997). Domestic and Systemic Determinants of Capital Controls in the Developed and Developing World. International Studies Quarterly, 41(3), 435-454.

Leblang, D. A. (2003). To Devalue or to Defend? The Political Economy of Exchange Rate Policy. International Studies Quarterly, 47(4), 533-560.

Linsi, L., \& Schaffner, F. (2019). When do Heuristics Matter in Global Capital Markets? The Case of the BRIC Acronym. New Political Economy, 24(6), 851-872.

López-Mejía, A. (1999). Large Capital Flows: Causes, Consequences, and Policy Responses. Finance and Development, 36(3), 28-31.

Magud, N. E., Reinhart, C. M., \& Rogoff, K.S. (2011). Capital Controls: Myth and Reality - A Portfolio Balance Approach. NBER Working Paper, 53(9), 1689-1699. Available at http://www.nber.org/ papers/w16805.

Marshall, M. G., Jaggers, K., \& Gurr, T.R. (2013). Polity IV. Available at http://www.systemicpeace.org/ polityproject.html.

McDowell, D. (2017). Need for Speed: The Lending Responsiveness of the IMF. The Review of International Organization, 12, 39-73.

Milner, H. V., \& Mukherjee, B. (2009). Democratization and Economic Globalization. Annual Review of Political Science, 12(1), 163-181.

Montecillo, P. G. (2013). BSP Lists Measures to Counter Volatility. Philippine Daily Inquirer. Available at http://business.inquirer.net/140353/bsp-lists-measures-to-counter-volatility.

Mosley, L. (2000). Room to Move: International Financial Markets and National Welfare States. International Organization, 54(4), 737-773.

Mukherjee, B., \& Singer, D. A. (2010). International Institutions and Domestic Compensation: The IMF and the Politics of Capital Account Liberalization. American Journal of Political Science, 54(1), 4560.

Naya, S., \& Plummer, M. G. (2005). The Economics of the Enterprise for ASEAN Initiative. Institute of Southeast Asian Studies.

Oatley, T. (2011). The Reductionist Gamble: Open Economy Politics in the Global Economy. International Organization, 65(2), 311-341. 
Oatley, T., Winecoff, W. K., Pennock, A., \& Danzman, S.B. (2013). The Political Economy of Global Finance: A Network Model. Perspectives on Politics, 11(1), 133-153.

Pagliari, M. S., \& Hannan, S. A. (2017). The Volatility of Capital Flows in Emerging Markets: Measures and Determinants. IMF Working Paper. Available at https:/www.imf.org/en/Publications/WP/Issues/ 2017/03/07/The-Volatility-of-Capital-Flows-in-Emerging-Markets-Measures-and-Determinants-44725.

Palma, S. (2018). Malaysia Central Bank Governor Wants Option of Capital Controls. Financial Times. Available at https://www.ft.com/content/c27c016e-cf7e-11e8-a9f2-7574db66bcd5.

Pepinsky, T. B. (2012). Do Currency Crises Cause Capital Account Liberalization?. International Studies Quarterly, 56(3), 544-559.

Pepinsky, T. B. (2012). The Global Economic Crisis and the Politics of Non-Transitions. Government and Opposition, 47(2), 135-161.

Pond, A. (2018). Worker Influence on Capital Account Policy: Inflow Liberalization and Outflow Restrictions. International Interactions, 44(2), 244-267.

Pradhan, M., Balakrishnan, R., Baqir, R., Heenan, G., Nowak, S., Oner, C., \& Panth, S. (2011). Policy Responses to Capital Flows in Emerging Markets. International Monetary Fund. Available at https:// www.imf.org/external/pubs/ft/sdn/2011/sdn1110.pdf.

Quinn, D. P., \& Inclán, C. (1997). The Origins of Financial Openness: A Study of Current and Capital Account Liberalization. American Journal of Political Science, 41(3), 771-813.

Quinn, D. P., \& Toyoda, A. M. (2007). Ideology and Voter Preferences as Determinants of Financial Globalization. American Journal of Political Science, 51(2), 344-363.

Quinn, D. P., \& Woolley, J. T. (2001). Democracy and National Economic Performance: The Search for Stability. American Journal of Political Science, 45(3), 634-657.

Reinhart, C. M., \& Rogoff, K. S. (2013). Banking Crises: An Equal Opportunity Menace. Journal of Banking and Finance, 37(11), 4557-4573.

Shambaugh, J. C. (2004). The Effect of Fixed Exchange Rates on Monetary Policy. The Quarterly Journal of Economics, 119(1), 301-352.

Simmons, B. A. (2000a). International Law and State Behavior: Commitment and Compliance in International Monetary Affairs. American Political Science Review, 94(04), 819-835.

Simmons, B. A. (2000b). Money and the Law: Why Comply with the Public International Law of Money. The Yale Journal of International Law, 25, 323.

Simmons, B. A., \& Elkins, Z. (2004). The Globalization of Liberalization: Policy Diffusion in the International Political Economy. American Political Science Review, 98(01), 171-189.

Steinberg, D., McDowell, D., \& Gueorguiev, D. (2020). Inside Looking Out: How International Policy Trends Shape the Politics of Capital Controls in China. The Pacific Review, 1-27.

Steinberg, D. A., \& Nelson, S. C. (2019). The Mass Political Economy of Capital Controls. Comparative Political Studies, 52(11), 1575-1609.

Terman, R., \& Voeten, E. (2018). The Relational Politics of Shame: Evidence From the Universal Periodic Review. Review of International Organizations, 13(1), 1-23.

Tomz, M. (2007). Reputation and International Cooperation: Sovereign Debt across Three Centuries. Princeton, NJ: Princeton University Press.

Walter, B. (2006). Building Reputation: Why Governments Fight Some Separatists but Not Others. American Journal of Political Science, 50(2), 313-330.

Weisiger, A., \& Yarhi-Milo, K. (2015). Revisiting Reputation: How Past Actions Matter in International Politics. International Organization, 69(2), 473-495.

Wolford, S. (2007). The Turnover Trap: New Leaders, Reputation, and International Conflict. American Journal of Political Science, 51(4), 772-788.

Publisher's note Springer Nature remains neutral with regard to jurisdictional claims in published maps and institutional affiliations. 